\title{
Impact of water column reduction rate at harvesting of Nile tilapia (oreochromis niloticus) on skin injuries, hematological and biochemical parameters and bacterial load of fish and water: a field study
}

\section{Radi A. Mohamed ${ }^{* 1}$, Fatma Abouelenien ${ }^{2}$, Nagham Elsaidy ${ }^{2}$, Ahmed Hamza $^{3}$ \\ 1- Department of Hygiene and Preventive Medicine (Animal Behavior and Welfare), Faculty of Veterinary Medicine, Kafrelsheikh University (33156), Egypt.}

2- Department of Hygiene and Preventive Medicine (Animal, Poultry and Environmental Hygiene), Faculty of Veterinary Medicine, Kafrelsheikh University (33156), Egypt.

3- Consultant of fish quality and hygiene, general authority of Veterinary Medicine, Kafr El-sheikh branch, Egypt.

Email : radiali_2007@yahoo.co.uk

\section{ABSTRACT}

The aim of this study was to evaluate the impact of reduced water column in different periods on health and welfare of the Nile tilapia during harvesting. As a common practice for gathering and harvesting of tilapia in Egypt, the water column was reduced gradually until reach the lowest level $(30 \mathrm{~cm})$. The water column was reduced from 150 to $30 \mathrm{~cm}$ in different periods as follow; Group1 (G1, control group), at which the water column was reduced from 150 to $30 \mathrm{~cm}$ in 72 hour (h). Group 2 (G2), at which the water column was reduced from 150 to $30 \mathrm{~cm}$ in $48 \mathrm{~h}$. Group 3 (G3), at which the water column was reduced from 150 to $30 \mathrm{~cm}$ in $24 \mathrm{~h}$.

The results showed that, there was a significant $(P<0.05)$ decrease in muscle total bacterial count (TBC), fish injuries, heterophil /lymphocyte $(\mathrm{L} / \mathrm{H})$ ratio, serum glucose, Lactate dehydrogenase, alkaline phosphatase and an increase in water, skin TBC, dissolved oxygen (DO), unionized ammonia (UIA), and total leucocyte count (TLC) in G3 compared to G2 and G1.

In conclusion, the process of reduced water column before gathering and harvesting needs to be carried out within $24 \mathrm{~h}$ to reduce injuries and bacterial load of fish. In addition, it improves the immune system and health of fish that reducing the risk of infection. Therefore, slow reduction of water column height during harvesting produces crowding stress altering health status and welfare of Nile tilapia (Oreochromis niloticus).

Keywords: Fish harvesting; water column; skin injuries; water quality; bacteriological parameters; fish welfare

\section{INTRODUCTION}

Fish welfare is an important issue for the industry, not just for public perception, marketing and product acceptance, but also often in terms of production efficiency, quality and quantity (Broom, 2010; Southgate and Wall, 2002). Several studies defined the welfare of fish through fisheries, aquaculture and other activities as physical, physiological and behavioural conditions facing the animal in aquaculture environment (Huntingford et al., 2006; Braithwaite and Boulcott 2007).

According to FAWC (1996) and Chandroo et al., (2004) in order to achieve farmed fish welfare the following freedoms must be provided; 1) sufficient and nutritionally diet, with starvation before slaughter and transport for short time. 2) adequate water quality parameters (dissolved oxygen, $\mathrm{NH}_{3}, \mathrm{pH}$ and turbidity), flow rates, temperatures and appropriate light intensities. 3) careful procedures for avoiding 
injuries, malformation, infections and diseases, through the application of best management practices during the rearing period, harvesting, good hygienic conditions and proper vaccination. 4) adequate space and appropriate facilities to express normal behaviour. 5) providing suitable living conditions by which physical and mental suffering could be avoided.

In Egypt, tilapia is reared mainly in earthen ponds in a semi extensive rearing system. Following a period of fasting, tilapias are netted and placed in ice, in water or in dry crates for transportation to the wholesale or point of slaughter. There are numerous conditions and activities used during aquaculture practices, which cause stress (chronic or acute) and promote a reduction of welfare (Conte, 2004). The harvesting process (length, intense handling, crowding during most of the catching protocols and related decrease of oxygen) could be a very traumatic time for the farmed fish, involving the onset of a stress status, which can compromise the organoleptic, merchantable and sanitary quality of the final product (Poli, 2009).

Crowding is the first stage in most gathering, harvesting and transport operations. In ponds, it is achieved by reducing the height of water column and the use of a special net or by moving partitions or trellises. Wall (2001) stated that crowding is one of the prime causes of poor welfare during harvest. Ortuno et al. (2001) stated that the most common problem associated with crowding is shortage of oxygen. However, even when oxygen level is maintained, crowding changes many other aspects of the fish physiology, which can be observed for days afterwards. Fish respond to crowding will differ according to species, some studies have suggested that skin damage intensifies with increasing stocking density in rainbow trout (North et al., 2006) and sea bass (Person-Le Ruyet and Le Bayon, 2009), but others have reported that stocking density has no effect in Atlantic salmon (Hosfeld et al., 2009).

During harvesting in fishponds, the densities of fish could be changed from few kilograms to several hundred kilograms per square meter. The vigorous swimming during crowding implies an intense use of the white muscle increasing anaerobic glycolysis with subsequent lactic acid production and lowering of muscle $\mathrm{pH}$ (Poli et al., 2005). Additionally, under these conditions there are particular dangers to the fish of bruising, crushing, puncture and abrasion injuries from contact with other fish, contact with the net and contact through the net with other hard surfaces. So, the process of gathering and harvesting needs to be carried out unhurriedly and with great care to avoid a panic reaction in the fish, which could result in high levels of stress and mortality (Brown et al., 2010). As poor crowding technique is likely to result in external injury and mortality, fish producers are trying to protect their fish from possible injurious circumstances as part of their ethical and general responsibility towards their reared animals. The main skin lesions associated with gathering and harvesting practices were skin abrasions and injuries that characterised by a cut-off of the skin layers (epidermis). In addition, it might be accompanied with detachment of scales and subcutaneous haemorrhage (Noble et al., 2012). From the production outlook, injuries can lead to reduced feed intake (Dykova et al., 1998), reduced growth rate (Miyashita et al., 2000), increased susceptibility to bacterial infection and parasitic infestation (Turnbull et al., 1996) and increased mortality rate (Cobcroft and Battaglene, 2009). In addition, injuries can reduce the market value of farmed fish and its keeping quality (Michie, 2001).

Changes in pond water parameters especially, $\mathrm{DO}, \mathrm{NH}_{3}, \mathrm{pH}$, and turbidity, and bacterial load were resulted from crowding of fish (Bhatnagar and Devi, 2013) during harvesting and expectedly these changes will affect the quality of the harvested fish. In intensive systems, Ammonia is the most important parameter after oxygen that 
affects fish. The un-ionized form of ammonia (UIA) is the most toxic form to aquatic life (Alabaster and Lloyd, 1980; Adams et al., 2001; Abouelenien et al., 2015).

The impact of the time elapsed in reduction of water column at gathering and harvesting of fish on water quality and consequently fish injuries and welfare has not been investigated previously to our knowledge. Therefore, the present work was carried out to study the effect of time elapsed in reduction of water column height during gathering and harvesting of Nile tilapia (O. niloticus) on fish injuries, hematological and biochemical assay and bacterial load and its consequences on fish welfare.

\section{MATERIALS AND METHODS}

\section{Fish, rearing system and management}

This study was carried out in a private fish farm at Kafr El-Sheikh governorate (N: 31, 21, 38 and E: 30, 36, and 40). The farm was composed of eight independent ponds, six for breeding and two for brooding. All ponds were irrigated from a single water source but each pond has a separate water inlet and outlet. The surface area of each breeding pond was 2 Acres and the pond dimensions were $150 \times 55 \times 1.5 \mathrm{~m}$. The fish type was mono-sex Nile tilapia (O. niloticus) was treated with 17 alpha methyl testosterone with Mugil cephalos and Mugil capitos. The rearing system was a semi extensive system and the average fish density was 3 fish $/ \mathrm{m}^{2}$. The fish feed was pelleted sinking type, $3 \mathrm{~mm}$ in diameter. The feeding rate ranged from $4 \%$ from the fish biomass at the beginning of the rearing period to $1.5 \%$ at the end of the rearing period, twice daily. Composition and proximate analyses of commercial fish feed used for Nile tilapia (O. niloticus) was illustrated in Table 1. The rearing period was 7 months, started at April 2014 with 20 g fingerlings.

Table 1: Composition and proximate analyses of commercial fish feed used for Nile tilapia (Oreochromis niloticus).

\begin{tabular}{|l|c|}
\hline Ingredients & $\%$ \\
\hline Corn & 9 \\
Rice bran & 16 \\
Wheat milling by product & 10 \\
Wheat barn & 9 \\
Soya bean pellets (47) & 36 \\
Poultry meal & 5 \\
Fish meal (60) & 5 \\
Gluten & 2.5 \\
Sun flower meal & 3 \\
Dicalcium phosphate & 1.2 \\
Salt & 1 \\
Dry fat & 0.8 \\
Soya oil & 1 \\
Vitamins and minerals & 0.5 \\
\hline Proximate analysis & \\
Dry Matter & 91 \\
Moisture & 9 \\
Protein & 30 \\
Fat & 7 \\
Fiber & 7 \\
Ash & 6.5 \\
Digestible energy (DE) & 33.5 \\
\hline
\end{tabular}




\section{Experimental design}

During the rearing period of fish, the height of water column in the breeding ponds ranged from 130 to $150 \mathrm{~cm}$ and not less than $145 \mathrm{~cm}$ during the last month of the rearing period. As a common practice for gathering and harvesting of tilapia in Egypt, the water column was reduced gradually until reach the lowest level $(30 \mathrm{~cm})$. In this experiment, the water column was reduced from 150 to $30 \mathrm{~cm}$ in different periods as follow; Group1 (G1, control group), at which the water column was reduced from 150 to $30 \mathrm{~cm}$ in 72 hour (h). Group 2 (G2), at which the water column was reduced from 150 to $30 \mathrm{~cm}$ in $48 \mathrm{~h}$. Group 3 (G3), at which the water column was reduced from 150 to $30 \mathrm{~cm}$ in $24 \mathrm{~h}$. G1 chosen as a control group, because it is the usual practice done in fish farms in Egypt.

\section{Sampling}

\section{Water sampling}

Water sampling was done around time of fishing. Five water samples were collected from each pond by inverting $250 \mathrm{ml}$ sterilized glass bottle $15 \mathrm{~cm}$ below the pond water surface. All samples were transferred to the lab on icebox. Analysis was initiated within $2 \mathrm{~h}$ of sample collection.

\section{Fish sampling}

To reduce stress, fish were rapidly netted, then anesthetized with a buffered solution of $70 \%$ benzocaine (Sigma Chemical Co., USA).

\section{Fish injuries, detached scales and external hemorrhage}

Twenty-four fish from each pond were caught from different sites of fish pond by using a net. Each fish was handled and fixed on a table. The number of injuries in head, body, dorsal fin, tail and tail fin were estimated with the help of an optical magnifier lens (x10). Presence of external hemorrhage (outer bleeding) and detached scales (few, scattered detached scales; intermediate, detached scales formed a patch less than $0.25 \mathrm{~cm}^{2}[0.5 \mathrm{x} 0.5 \mathrm{~cm}$ ]; sever, detached scales formed a patch equal to or more than $0.25 \mathrm{~cm}^{2}$ ) were estimated with the help of an optical magnifier lens (x10) and measuring board. Frequency of injuries, detached scales and outer bleeding was calculated as a percentage of total examined fish ([number of fish suffering/ total number of examined fish] x 100).

\section{Skin sampling}

Sterile cotton bud was used to take a swap from the surface of the fish immediately upon collection from the pond. The cotton bud was placed immediately in $5 \mathrm{ml}$ sterile peptone water in sterile plastic applicator (Rayon), labeled and kept at $4^{\circ} \mathrm{C}$ and transported to the laboratory.

\section{Muscle sampling}

Twelve live fish from each pond were randomly selected from the catch at each sampling time. In the laboratory each fish was rinsed with de-ionized water and the surface of the fish decontaminated by dipping it in ethyl alcohol and lightly flames. Fish were dissected according to the method described by Buras et al. (1987). Muscles were isolated and placed in a sterile polyethylene bag; the tissues were weighed under sterile condition. Ten grams of muscle portion of fish along with skin were homogenized for $1 \mathrm{~min}$ with $90 \mathrm{ml}$ of physiological saline ( $\mathrm{Nacl} 0.85 \%$ ) in a homogenizer (Polytron $\left.{ }^{\circledR P T}-M R ~ 2100\right)$. One $\mathrm{ml}$ of the homogenate for skin and muscle samples was serially diluted $\left(10^{-1}\right.$ to $\left.10^{-8}\right)$ as described by the study of AlHarbi (2003).

\section{Blood sampling}

Blood was drawn from the caudal peduncle region (caudalis vein) using a 23gauge needle of 24 fish from each pond. 


\section{Analytical methods \\ Bacteriological examinations}

The total bacterial count of water and skin samples was carried out according to Cruickshank et al. (1972). The total bacterial count of fish samples was carried out according to the method of APHA (1998).

\section{Physico-chemical examination of water samples}

Water temperature, $\mathrm{pH}$ and dissolved oxygen (DO) were measured in situ with (a Yellow Springs dissolved oxygen meter Model 54A). Pond water $\mathrm{pH}$ and temperature were determined using an Adwa AD11 and AD12 (Romania).

Total ammonia $\left(\mathrm{NH}_{3}\right.$, Electrical conductivity (EC), total dissolved solids (TDS) were measured by the standard methods described by APHA (1998).

\section{Hematological and biochemical parameters}

The blood samples were held on ice until all samples were collected. Hematological and biochemical analyses were performed within $2 \mathrm{~h}$ of blood collection.

\section{Hematological analysis}

One ml whole blood was taken in EDTA tubes for estimation of WBC (total leucocyte count) and differential leukocytes count for calculation of $\mathrm{H} / \mathrm{L}$ ratio according to the method of Svobodova et al. (1991).

\section{Biochemical analysis}

One $\mathrm{ml}$ blood was taken in vacuum tubes. Blood was centrifuged at $3000 \mathrm{rpm}$ for $10 \mathrm{~m}$ for serum separation. Serum was stored at-40 $\dot{\mathrm{C}}$ for further assay of glucose, Lactate dehydrogenase (LD) and alkaline phosphatase (ALP). Assays were performed as described by Nelson et al. (1944), Palti et al. (1999) and Anderson and Siwicki (1995).

\section{Statistical analysis}

Data were tested for distribution normality, linearity and homogeneity of variance. Data were analysed using Graph Pad ${ }^{\mathrm{TM}}$ Prism 5. Results are presented as means \pm SEM. Data were compared by one way ANOVA and the Tukey's Multiple Comparison Test was used as a post hoc test when appropriate. The significance level was $P<0.05$.

\section{RESULTS}

The results in Table 2 revealed that there were significant differences $(P<0.05)$ among the analysed water parameters except for water temperature and ammonia. For unionized ammonia the highest numerical value was found in G3 $(0.627 \mathrm{ppm})$ and the lowest in G2 followed by G1. For $\mathrm{pH}$ and $\mathrm{EC}$, there was no significant difference between integral water column $(1.5 \mathrm{~m})$ and reduced water column $(0.3 \mathrm{~m})$ in different periods of time $(72,48$, and $24 \mathrm{~h})$. While, there was no significant differences between G1 and G2 but they were significantly differed $(P<0.05)$ from G3. For TDS, there was a significant difference $(P<0.05)$ between integral water column $(1.5 \mathrm{~m})$ and reduced water column $(0.3 \mathrm{~m})$ in different groups. However, there was no significant difference between G1 and G3 but they were significantly differed from G2. The lowest concentration of $\mathrm{NH}_{3}$ was recorded in integral water column $(1.5 \mathrm{~m})$ followed by G3, G2 and G1 in reduced water column $(0.3 \mathrm{~m})$. Additionally, there was a significant difference $(\mathrm{P}<0.05)$ in $\mathrm{TBC}\left(\log _{10} \mathrm{cfu} / \mathrm{ml}\right)$ among water samples from different groups. Where water from G3 recorded the highest TBC $\left(\log _{10} \mathrm{cfu} / \mathrm{ml}\right)$, followed by water samples from ponds have been reduced in $48 \mathrm{~h}(\mathrm{G} 2)$ and $72 \mathrm{~h}(\mathrm{G} 1)$ 
respectively. While, they were significantly $(\mathrm{P}<0.05)$ higher at $\mathrm{TBC}\left(\log _{10} \mathrm{cfu} / \mathrm{ml}\right)$ than water samples at water column $1.5 \mathrm{~m}$.

Table 2: Effect of water column reduction rate at harvesting on water parameters and total bacterial count of Nile tilapia (Oreochromis niloticus) fish.

\begin{tabular}{|l|c|c|c|c|}
\hline parameter & $\begin{array}{c}\text { Integral water column } \\
(150 \mathrm{~cm})\end{array}$ & \multicolumn{3}{|c|}{ Time spent to reduce water column from 150 to $30 \mathrm{~cm}$} \\
\cline { 3 - 5 } & $12.000 \pm 0.32$ & $11.600 \pm 0.400$ & $12.000 \pm 0.320$ & $12.200 \pm 0.370$ \\
\hline Water temp. $\left({ }^{\circ} \mathrm{C}\right)$ & $6.240 \pm 0.23^{\mathrm{cd}}$ & $4.930 \pm 0.146^{\mathrm{ab}}$ & $5.340 \pm 0.133^{\mathrm{b}}$ & $5.860 \pm 0.187^{\mathrm{c}}$ \\
\hline $\mathrm{DO}(\mathrm{mg} / \mathrm{L})$ & $7.620 \pm 0.17^{\mathrm{a}}$ & $7.436 \pm 0.106^{\mathrm{ac}}$ & $7.284 \pm 0.279^{\mathrm{ac}}$ & $8.246 \pm 0.045^{\mathrm{ab}}$ \\
\hline $\mathrm{PH}$ & $16.240 \pm 0.56^{\mathrm{b}}$ & $21.840 \pm 0.90^{\mathrm{a}}$ & $20.720 \pm 2.10^{\mathrm{ab}}$ & $18.880 \pm 1.37^{\mathrm{ab}}$ \\
\hline $\mathrm{NH}_{3}(\mathrm{ppm})$ & $0.140 \pm 0.005^{\mathrm{c}}$ & $0.118 \pm 0.004^{\mathrm{b}}$ & $0.070 \pm 0.003^{\mathrm{a}}$ & $0.627 \pm 0.004^{\mathrm{d}}$ \\
\hline $\mathrm{UIA}(\mathrm{ppm})$ & $1.473 \pm 0.007^{\mathrm{c}}$ & $1.558 \pm 0.005^{\mathrm{b}}$ & $1.618 \pm 0.019^{\mathrm{a}}$ & $1.532 \pm 0.004^{\mathrm{b}}$ \\
\hline TDS $(\mathrm{g} / \mathrm{L})$ & $3.062 \pm 0.007^{\mathrm{a}}$ & $3.100 \pm 0.001^{\mathrm{ab}}$ & $3.240 \pm 0.036^{\mathrm{ab}}$ & $2.868 \pm 0.108^{\mathrm{ac}}$ \\
\hline EC $\left.(\mathrm{dSm})^{-1}\right)$ & $5.442 \pm 0.36^{\mathrm{b}}$ & $6.027 \pm 0.51^{\mathrm{ab}}$ & $6.548 \pm 0.340^{\mathrm{ab}}$ & $7.797 \pm 0.620^{\mathrm{a}}$ \\
\hline Water TBC $\left(\log _{10} \mathrm{cfu} / \mathrm{ml}\right)$ & ------- & $5.663 \pm 0.350$ & $5.574 \pm 0.340$ & $6.206 \pm 0.240$ \\
\hline Skin TBC $\left(\log _{10} \mathrm{cfu} / \mathrm{g}\right)$ & ------ & $6.674 \pm 0.290$ & $6.542 \pm 0.340$ & $6.450 \pm 0.380$ \\
\hline Muscle TBC $\left(\log _{10} \mathrm{cfu} / \mathrm{g}\right)$ & & &
\end{tabular}

In each row, means having different small superscripts differ significantly $(P<0.05)$

G1, Group1; at which the water column was reduced from 150 to $30 \mathrm{~cm}$ in $72 \mathrm{~h}$. G2, Group 2; at which the water column was reduced from 150 to $30 \mathrm{~cm}$ in $48 \mathrm{~h}$. G3, Group 3; at which the water column was reduced from 150 to $30 \mathrm{~cm}$ in $24 \mathrm{~h}$.

DO; dissolved oxygen, UIA; unionized Ammonia, TDS; total dissolved oxygen, EC; Electric conductivity, TBC; total bacterial count.

Results of TBC for skin and muscle samples of fish ( $\left.\log _{10} \mathrm{cfu} / \mathrm{g}\right)$ which caught from ponds of different reduced water column times showed no significant difference at among examined samples (Table 2). However, skin samples of G3 recorded high levels of TBC (6.206 \pm 0.240$)$, followed by $5.663 \pm 0.350$ and $5.574 \pm 0.340$ for G1 and G2 respectively (Table 2). Muscle samples of G3 recorded lower levels for TBC $(6.450 \pm 0.380)$ while muscle samples of G2 $(6.542 \pm 0.340)$ and G1 $(6.674 \pm 0.290)$ recorded insignificant increases as compared with G3.

The results in Table 3 showed reducing the height of water column from 150 to $30 \mathrm{~cm}$ before harvesting has a significant $(P<0.05)$ effect on fish injury. Reducing the height of water column in G1 recorded the highest levels of injuries in head, body and dorsal fin, tail and tail fin regions. While the reduction of water column in G2 and G3 recorded the lowest levels of injuries in the same fish regions respectively. The percentage of head, body and dorsal fin, tail and tail fin injury was the highest in G1, followed by G2 and G3 respectively (Fig. 1).

Table 3: Effect of water column reduction rate at harvesting on external injuries (number) of Nile tilapia (Oreochromis niloticus) fish.

\begin{tabular}{|l|c|c|c|}
\hline \multirow{2}{*}{ Fish part } & \multicolumn{3}{|c|}{ Time spent to reduce water column from 150 to $30 \mathrm{~cm}$} \\
\cline { 2 - 4 } & $\mathrm{G} 1(72 \mathrm{~h})$ & $\mathrm{G} 2(48 \mathrm{~h})$ & $\mathrm{G} 3(24 \mathrm{~h})$ \\
\hline Head & $0.83 \pm 0.28^{\mathrm{a}}$ & $0.25 \pm 0.09^{\mathrm{b}}$ & 0.0 \\
\hline Body and dorsal fin & $2.17 \pm 0.32^{\mathrm{a}}$ & $1.08 \pm 0.20^{\mathrm{b}}$ & $0.83 \pm 0.19^{\mathrm{b}}$ \\
\hline Tail and tail fin & $0.83 \pm 0.14^{\mathrm{a}}$ & $0.67 \pm 0.10^{\mathrm{a}}$ & $0.25 \pm 0.09^{\mathrm{b}}$ \\
\hline
\end{tabular}

In each row, means having different small superscripts differ significantly $(P<0.05)$

G1, Group1; at which the water column was reduced from 150 to $30 \mathrm{~cm}$ in $72 \mathrm{~h}$. G2, Group 2; at which the water column was reduced from 150 to $30 \mathrm{~cm}$ in $48 \mathrm{~h}$. G3, Group 3; at which the water column was reduced from 150 to $30 \mathrm{~cm}$ in $24 \mathrm{~h}$. 


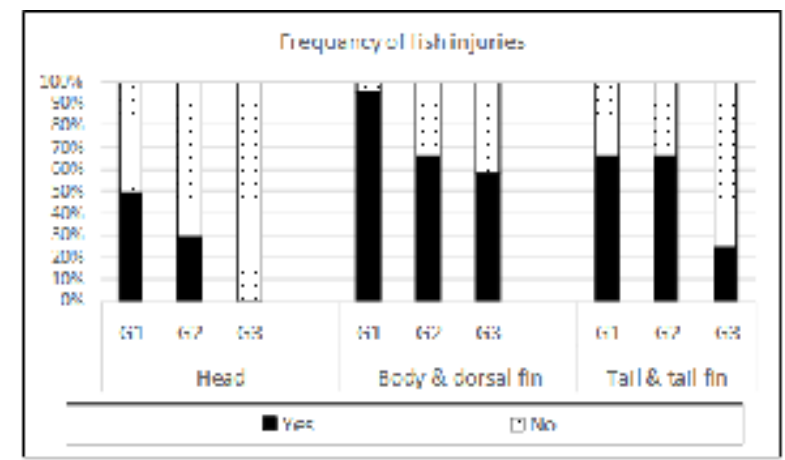

Fig.1: Effect of water column reduction rate at harvesting on frequency (Percentage) of injuries (black, yes) or absence of injuries (white, no) in head, body and dorsal fin, tail and tail fin of Nile tilapia (Oreochromis niloticus).

G1, Group1; at which the water column was reduced from 150 to $30 \mathrm{~cm}$ in $72 \mathrm{~h}$. G2, Group 2; at which the water column was reduced from 150 to $30 \mathrm{~cm}$ in $48 \mathrm{~h}$. G3, Group 3; at which the water column was reduced from 150 to $30 \mathrm{~cm}$ in $24 \mathrm{~h}$.

The percentage of fish suffering from detached scales was few detached scales (70.83, 70.83, and $83.33 \%)$, intermediate detached scales $(20.83,20.83$, and $16.67 \%)$ and sever detached scales $(8.34,8.34,0 \%)$ in response to the reduction of water column height from 150 to $30 \mathrm{~cm}$ in 72, 48, and $24 \mathrm{~h}$ respectively (Fig. 2). While, the highest percentage of outer bleeding in fish was recorded in G2, followed by G1 and G3 respectively (Fig. 3).

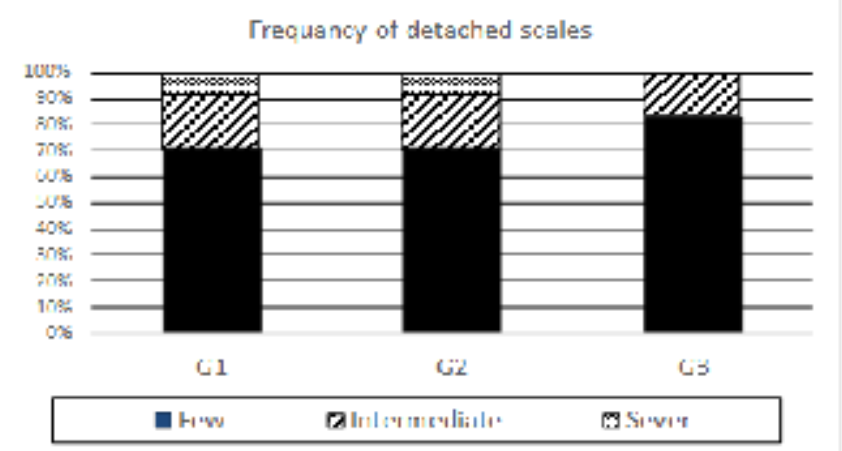

Fig. 2: Effect of water column reduction rate at harvesting on frequency (Percentage) of detached scales (black, few - bands, intermediate - dotted, sever) of Nile tilapia (Oreochromis niloticus). G1, Group1; at which the water column was reduced from 150 to $30 \mathrm{~cm}$ in $72 \mathrm{~h}$. G2, Group 2; at which the water column was reduced from 150 to $30 \mathrm{~cm}$ in $48 \mathrm{~h}$. G3, Group 3; at which the water column was reduced from 150 to $30 \mathrm{~cm}$ in $24 \mathrm{~h}$.

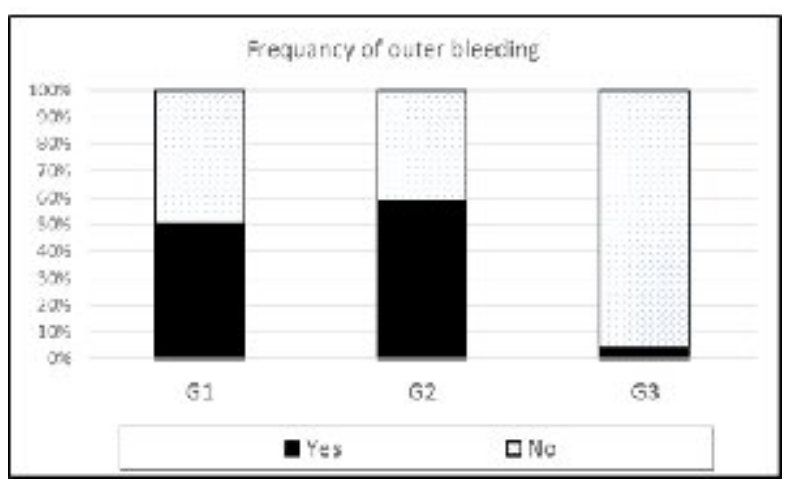

Fig. 3: Effect of water column reduction rate at harvesting on frequency (Percentage) of outer bleeding

(Black, yes) or absence of outer bleeding (White, no) of Nile tilapia (Oreochromis niloticus).

G1, Group1; at which the water column was reduced from 150 to $30 \mathrm{~cm}$ in $72 \mathrm{~h}$. G2, Group 2; at which the water column was reduced from 150 to $30 \mathrm{~cm}$ in $48 \mathrm{~h}$. G3, Group 3; at which the water column was reduced from 150 to $30 \mathrm{~cm}$ in $24 \mathrm{~h}$. 
The results in Table 4 showed that there was a significant difference $(P<0.05)$ in hematological and biochemical parameters estimated in fish among the experimental groups. The results of TLC showed significant higher level in G2 and G3 than level of G1. The activity of LD was significantly higher in G1 and G2 than its activity in G3. For $\mathrm{H} / \mathrm{L}$ ratio and $\mathrm{LD}$, there was no significant difference between $\mathrm{G} 1$ and $\mathrm{G} 2$ but they were significantly different $(P<0.05)$ from G3. In case of glucose level, there was a significant difference $(P<0.05)$ between all groups. While for ALP, there was no significant difference between G2 and G3 but they were significantly different $(P<0.05)$ from $\mathrm{G} 1$.

Table 4: Effect of water column reduction rate at harvesting on hematological and biochemical parameters of Nile tilapia (Oreochromis niloticus) fish.

\begin{tabular}{|l|c|c|c|}
\hline \multirow{2}{*}{ parameter } & \multicolumn{2}{|c|}{ Time spent to reduce water column from 150 to $30 \mathrm{~cm}$} \\
\cline { 2 - 4 } & $\mathrm{G} 1(72 \mathrm{~h})$ & $\mathrm{G} 2(48 \mathrm{~h})$ & $\mathrm{G} 3(24 \mathrm{~h})$ \\
\hline TLC $(/ \mu \mathrm{l})$ & $35,550 \pm 676.400^{\mathrm{b}}$ & $39,400 \pm 891.2^{\mathrm{a}}$ & $40,050 \pm 801.600^{\mathrm{a}}$ \\
\hline H/L ratio & $0.060 \pm 0.004^{\mathrm{a}}$ & $0.051 \pm 0.003^{\mathrm{a}}$ & $0.024 \pm 0.002^{\mathrm{b}}$ \\
\hline Glucose $(\mathrm{mg} / \mathrm{dL})$ & $263.600 \pm 29.180^{\mathrm{a}}$ & $190.200 \pm 12.840^{\mathrm{b}}$ & $120.000 \pm 5.740^{\mathrm{c}}$ \\
\hline LD $(\mathrm{IU} / \mathrm{L})$ & $2578.000 \pm 118.4^{\mathrm{a}}$ & $3232.000 \pm 350.900^{\mathrm{a}}$ & $1653.000 \pm 101.000^{\mathrm{b}}$ \\
\hline ALP $(\mathrm{U} / \mathrm{L})$ & $24.000 \pm 0.695^{\mathrm{a}}$ & $14.800 \pm 0.504^{\mathrm{b}}$ & $13.200 \pm 0.961^{\mathrm{b}}$ \\
\hline
\end{tabular}

In each row, means having different small superscripts differ significantly $(P<0.05)$

TLC; total leucocyte count, H/L ratio; heterophils to lymphocytes ratio; LD; Lactate dehydrogenase, APK; Alkaline phosphatase.

G1, Group1; at which the water column was reduced from 150 to $30 \mathrm{~cm}$ in $72 \mathrm{~h}$. G2, Group 2; at which the water column was reduced from 150 to $30 \mathrm{~cm}$ in $48 \mathrm{~h}$. G3, Group 3; at which the water column was reduced from 150 to $30 \mathrm{~cm}$ in $24 \mathrm{~h}$.

\section{DISCUSSION}

As far as the authors know, this is the first work taking in consideration the effects of reduced water column in different periods on health and welfare of the Nile tilapia during harvesting. As a common practice during harvesting of tilapia in Egypt, the height of fishpond water column should be reduced to its lowest level. It mainly lead to sever condition of overcrowding and an increase in fish stocking density, which in turn have a detrimental effects on fish health and welfare.

The skin of fish is considered as a natural and biological barrier encompassing in ion regulation (Esteban, 2012; Benhameda et al., 2014) and providing the protection against friction that mainly originated from overcrowding (Daniel, 1981). On the other hand, skin providing protection against pollution in the aquatic environment and infectious agents (Ellis, 2001; Benhameda et al., 2014). Skin injuries are direct damage or visible losses of epidermis layers, which may lead to skin discolouration, detachment of outer scales and may be hemorrhage. It not only accompanied with poor fish welfare (Huntingford et al., 2006) but also causing production losses (Vagsholm and Djupvik, 1998; Ellis et al., 2008). In the present study, the main skin lesions associated with the reduction of water column height during fish harvesting from 150 to $30 \mathrm{~cm}$ were abrasions characterised by a discontinuity of the skin layer and sometimes accompanied by detachment of outer scales and subcutaneous hemorrhage in head, body, dorsal fin, tail and tail fin. The injuries of body and dorsal fin were the highest compared to head, tail and tail fin. The overall means of fish injuries were the lowest in the group suffered from reduced the height of water column in $24 \mathrm{~h}$ (G3) compared to 48 (G2) and $72 \mathrm{~h}(\mathrm{G} 1)$. This was accompanied by very low percentage of detached scales and outer hemorrhage in G3 compared to G2 and G1. These results could be explained as follow; the reduction of 
water column height in $24 \mathrm{~h}$ reduced the time for fish friction by contact with other fishes, nets and other hard surfaces during harvesting, consequently reducing the fish injuries and outer hemorrhage (Daniel, 1981). The reduction in the process of injury, detachment of outer scales and hemorrhage have a direct effect upon the reduction of pain sensation and nervousness as fish own free nerve cells that cover the skin surface and responsible for pain sensation (Kotrschal et al. 1993; Meka, 2004). These nerve cells contain special fibres that are involved in pain sensitivity. Roques et al. (2010) reported that there was an acute response to a painful stimulus, caudal fin clipping, in Nile tilapia (Oreochromis niloticus). The findings of Roques et al. (2010) was supported by increased Nile tilapia swimming activity up to $6 \mathrm{~h}$ after the damage occurred. The evidence for lower degree of surface swimming behavior observed in G3 (24 h) compared to G2 and G1 (data not shown). Therefore, intensifying skin injury, detached scales and outer hemorrhage originated from slower reduction of water column height from 150 to $30 \mathrm{~cm}$ (G2 and G3) at harvesting may have an unfavourable effect upon survival of fish and may affect fish quality. It may also influence upon welfare due to being a direct cause of suffering through injury to living tissue (Ellis et al., 2008) and may increase susceptibility to infection.

There were significant differences among the analysed water parameters except for water temperature and ammonia. For unionized ammonia (UIA) the highest level was found in G3 and the lowest in G2 followed by G1. These values of UIA were concomitant the pond water $\mathrm{pH}$ in different groups (Abouelenien et al., 2010; Abouelenien et al., 2014; Abouelenien et al., 2015). The increase in $\mathrm{pH}$ values with regard to accumulation of ammonia due to decomposition of nitrogenous compounds by the microbial activities (Erkan and Ozden, 2008). In the current study, the highest UIA in G3 could be due to both rapid decrease in water column (24h) and sudden increase fish activity resulted in sudden increase in nitrogenous compound concentration of pond water (Randall and Tsui, 2002). This increase in nitrogenous compound concentration together with high water temperature enhanced the microbial degradation of these compounds with production of UIA (Farag, 2012). The estimated UIA in all groups of the present study was higher than optimum concentrations, 0.05 $\mathrm{mg} / \mathrm{l}$ (El-Sherif and EL-Feky, 2008).

The optimum growth of Tilapia is obtained at concentrations greater than 3 $\mathrm{mg} / \mathrm{l}$ (Ross, 2000) and it is highly tolerant to low DO concentration, $0.1 \mathrm{mg} / \mathrm{l}$ (Magid and Babiker, 1975). In this field study, the measured DO concentration in all groups was lower than that obtained by Rapatsa and Moyo (2013).

Time taken for reducing water column at fishpond was found to have an obvious effect on bacterial load of pond water. As it was clear that with increasing time of reducing water column there was subsequent decrease in bacterial load of pond water which recorded highest count in G3 and G2 was higher than G1. These results may be attributed to the combined effect of UV rays (Olayemi, 1993) and sedimentation (Ali and Osman, 2012).

Microbiological evaluation of fish aims to quantify the hygienic quality of fish. Fishes are conditioned by their environment and hence it is obvious that growing and harvesting environment of fishes are polluted chemically or microbiologically (Abouelenien et al., 2015; Boyd, 1984; Elsaidy et al., 2015). The concept that could explain the results of the higher TBC of skin samples of tilapia fish caught for G3 than that found for G2 and G1. The results that in agreement with A1 Harbi (2003) and Elsaidy et al. (2015) observed that bacterial load in fish samples was correlated with the bacterial levels in the aquatic environment. In contrast to the previous findings, muscle samples of G3 ( $24 \mathrm{~h}$ reduced water column ponds) recorded lower values for 
$\mathrm{TBC}$, which could be explained on the basis of reduced time for fish friction by contact with other fish, nets and other hard surfaces during harvesting.

Skin provides protection against pollution in the aquatic environment and infectious agents for fishes (Ellis, 2001). This fact is supported by lowest level of fish skin injuries observed in G3 compared to G2 and G1 of the present study. Also, these findings are in agreement with findings of Huess (1995), and Adedeji and Adetunji (2004) reporting that physical damage to fishes results in easy access of spoilage bacteria.

In the present study, fish held at high stocking density due to slow reduction in the water column height (72 and $48 \mathrm{~h}$ ) showed a significant low level of TLC and high levels of H/L ratio, glucose, LD and ALP. This reduction of TLC and increased H/L ratio may be due to the release of cortisol that produce an immunosuppressive effect in fish (Barton and Iwama, 1991; Dunier, 1996; Palikova et al., 2010; Roques et al., 2012) reducing circulating lymphocytes and increasing circulating heterophils (Pickering, 1984). Furthermore, it makes reduction in the welfare and increasing the susceptibility of fish to disease (Houghton and Matthews, 1990; Ballarin et al., 2004). As a secondary response of fish to the overcrowding stresses that, increase the blood glucose and make mobilisation of energy sources of fish. Higher energy mobilization due to the vigorous swimming during crowding that increase muscular activity, and denotes powerful use of white muscles and will increase blood lactate dehydrogenase production and lowering of muscle $\mathrm{pH}$, due to the shifting of fish metabolism to anaerobic glycolysis (Marx et al., 1997). Yada and Nakanishi, (2002) observed similar findings, chronical exposition to stressors elevated the concentration of cortisol and glucose as well as haematological changes that predisposition the fish immune system favouring the pathogen installation.

\section{CONCLUSION}

As a management procedure, the process of reduced water column before gathering and harvesting needs to be carried out within $24 \mathrm{~h}$ to reduce injuries and bacterial load of fish. In addition, it improves the immune system and health of fish that reducing the risk of infection. Therefore, slow reduction of water column height during harvesting produces crowding stress altering health status and welfare of Nile tilapia (Oreochromis niloticus). The authors recommended more investigations in management of fish water pond to improve fish welfare and product quality.

\section{ACKNOWLEDGEMENT}

The authors would like to thank Department of Hygiene and Preventive Medicine, Faculty of Veterinary Medicine, Kafr El-Sheikh University for funding the study.

\section{REFERENCES}

Abouelenien, F.; Elsaidy, N.; Kirrella, G.A. and Mohamed, R. A. (2015). Hygienic Effect of Supplementing Orechromis niloticus Farm with Fresh or Fermented Chicken Manure on: Water, Fish Quality and Performance. Aex J of Vet Sci, 45(1): 79-90.

Abouelenien, F.; Fujiwara, W.; Namba, Y.; Kosseva, M.; Nishio, N. and Nakashimada, Y. (2010). Improved methane fermentation of chicken manure via ammonia removal by biogas recycle. Bioresource technol, 101(16), 6368-6373. 
Abouelenien, F.; Namba, Y.; Kosseva, M.R.; Nishio, N. and Nakashimada, Y. (2014). Enhancement of methane production from co-digestion of chicken manure with agricultural wastes. Bioresource technol, 159, 80-87.

Adams, M.B.; Powell, M.D. and Purser, G.J. (2001). Effect of acute and chronic ammonia and nitrite exposure on oxygen consumption and growth of juvenile big bellied seahorse. J Fish Biol, 58, 848-860.

Adedeji, O.B. and Adetunji, V.O.(2004). Pests in Farm Animals and Stored Animal Products. Agriculture, Renewable Natural Resources, Animal Husbandry and Health. Published by General Studies Programme (GSP) University of Ibadan. Nigeria: pp $141-151$.

Alabaster, J.S. and Lloyd, R. (1980). Water Quality Criteria for Freshwater Fish. Butterworths, London.

Al-Harbi, A.H. (2003). Faecal coliforms in pond water, sediments and hybrid tilapia Orecochromis niloticus $\times$ Oreochromis aureus in Saudi Arabia. Aquacult Rese, 34:517-524.

Ali, M.S. and Osman, G.A. (2012). Microbiological load as pollution indicator in water of El-Khadraa Lake at Wadi El-Natroun, Egypt. International J. Agri Env, 4:41-48.

Anderson, D.P. and Siwicki, A.K. (1995). Basic haematology and serology for fish health programs. In: Fish Health Section (ed. By M. Sharii, J. R. Arthur and R.P. Subasinghe), pp.185-202. Asian Fisheries Society, Manila, Philippines.

APHA, (1998). Standard Methods for the Examination of Water and Wastewater, 20th edition. American Public Health Association, Washington, D.C.

Ballarin, L.; Dall'Oro, M.; Bertotto, D.; Libertini, A.; Francescon, A. and Barbaro, A. (2004). Haematological parameters in Umbrina cirrosa (Teleostei, Sciaenidae): a comparison between diploid and triploid specimens. Comp Biochem Physiol Part A: Molecular and Integrative Physiology, 138(1), 45-51.

Barton, B.A. and Iwama, G.K. (1991). Physiological changes in fish from stress in aquaculture with emphasis on the response and effects of corticosteroids. Ann Rev Fish Dis, I: 3-26.

Benhameda, S.; Guardiola, F.A.B.; Mars, M. and Estebanb, M.A. (2014). Pathogen bacteria adhesion to skin mucus of fishes. Vet Microbiol, 171: 1-12.

Bhatnagar, A. and Devi, P. (2013). Water quality guidelines for the management of pond fish culture. Int J Environ Sci, 3: 6.

Boyd, R.F. (1984). General Microbiology. Published by Times Mirror/Mosby College, pp. 459-461.

Braithwaite, V.A. and Boulcott, P. (2007). Pain perception, aversion and fear in fish. Dis Aquat Org., 75: 131-138.

Broom, D. (2010). Fish welfare and the public perception of farmed fish. In: Nash, C., Julien, V. (Eds.), Report Aquavision'98. The Second Nutreco Aquaculture Business Conference Stavanger Forum, Norway, pp.89-91.

Brown, J.A.; Watson, J.; Bourhill, A. and Wall, A. (2010). Physiological welfare of commercially reared cod and effects of crowding for harvesting. Aquaculture, 298:315-324

Buras, N.; Duek, L.; Niv, S.; Hepher, B. and Sandbank, E. (1987). Microbiological aspects of fish grown in treated wastewater. Water Res, 21(1):1-10.

Chandroo, K.P.; Duncan, I.J.H. and Moccia, R.D. (2004). Can fish suffer? Perspectives on sentience, pain, fear and suffering. Appl Anim Behav Sci, 86:225-250.

Cobcroft, J.M. and Battaglene, S.C. (2009). Jaw malformation in striped trumpeter Latrislineata larvae linked to walling behaviour and tank colour. Aquaculture, 289:274-282.

Conte, F.S. (2004). Stress and the welfare of cultured fish. Appl Anim Behav Sci, 86: 205-223. 
Cruickshank, R.; Duguid, J.P. and Swain, R.H.A. (1972). Hand book of bacteriology. 11th ED.E. and S. Livingstone limited Edinburgh and London.

Daniel, T.L. (1981). Fish Mucus-in situ measurements of polymer drag reduction. Biol Bull, 160:376-382.

Dunier, M. (1996). Water pollution and immunosuppression of freshwater fish. Ital J. Zool., 63(4): 303-309.

Dykova, I.; Figueras, A.; Novoa, B. and Casal, J.F. (1998). Paramoebasp. an agent of amoebic gill disease of turbot Scophthalmusmaximus. Dis Aquat Org., 33:137-141.

Ellis, A.E. (2001). Innate host defense mechanisms of fish against viruses and bacteria. Dev Comp Imm, 25:827-839.

Ellis, T.; Oidtmann, B.; St-Hilaire, S.; Turnbull, J.; North, B.; MacIntyre, C.; Nikolaidis, J.; Hoyle, I.; Kestin, S. and Knowles, T. (2008). Fin erosion in farmed fish. In: Branson E (ed) Fish welfare. Blackwell, Oxford; pp 121-149.

Elsaidy, N.; Abouelenien, F. and Kirrella, G.A.K. (2015). Impact of using raw or fermented manure as fish feed on microbial quality of water and fish. Egypt $\mathrm{J}$ Aquat Res, 41(1): 93-100.

El-Sherif, M.S.; El-Feky, A.M. (2008). Effect of ammonia on Nile Tilapia (O. niloticus) performance and some hematological and histological measures. Eighth International Symposium on Tilapia in Aquaculture, Cairo, Egypt.

Erkan, N. and Ozden, O. (2008). Quality assessment of whole and gutted sardines (Sardina pilchardus) stored in ice. Int J Food Sci, 1549-1555.

Esteban, M.A. (2012). An overview of the immunological defenses in fish skin. ISRN Immunol, 29 pages.

Farag, H.E.M. (2012). Sensory and chemical changes associated with microbial flora of Oreochromis niloticus stored in ice. Int Food Res J, 19: 447-453

FAWC, (1996). Report on the welfare of fish. [http://www.fawc.org.uk].

Hosfeld, C.D.; Hammer, J.; Handeland, S.O.; Fivelstad, S. and Stefansson, S.O. (2009). Effects of fish density on growth and smoltification in intensive production of Atlantic salmon (Salmo salar L.). Aquaculture, 294:236-241

Houghton, G. and Matthews, R.A. (1990). Immunosuppression in juvenile carp, Cyprinuscarpio L.: The effects of the corticosteroid triamcinolone acetonide and hydrocortisone 21-hemisuccinate (cortisol) on acquired immunity and the humoral antibody response to Ichthyophthiriusmultifiliis Fouquet. J Fish Dis, 13: 269-280.

Huntingford, F.A.; Adams, C.; Braithwaite, V.A.; Kadri, S.; Pottinger, T.G.; Sandøe, P. and Turnbull, J.F. (2006). Current issues in fish welfare. J. Fish Biol, 68:332-372.

Huss, H.H. (1995). Quality and Quality Changes in Fresh Fish. FAO Fisheries technical paper 348, FAO Rome, Italy.

Kotrschal, K.; Whitear, M. and Finger, T.E. (1993). Spinal and facial innervation of the skin in the gadid fish Ciliatamustela (teleostei). J Comp Neurol, 331:407-417.

Magid, A. and Babiker, M.M. (1975). Oxygen consumption and respiratory behavior of three Nile fishes. Hydrobiologia, 46:359-367.

Marx, H.; Brunner, B.; Weinzierl, W.; Hoffman, R. and Stolle, A. (1997). Methods of stunning freshwater fish: impact on meat quality and aspects of animal welfare. $Z$ Lebensm Unters Forsch, 204:282-286.

Meka, J.M. (2004). The Influence of Hook Type, Angler Experience, and Fish Size on Injury Rates and the Duration of Capture in an Alaskan Catch-and-Release Rainbow Trout Fishery N AM J Fish Manage, 24; 4.

Michie, I. (2001). Causes of downgrading in the salmon farming industry. In: Kestin SC, Warriss PD (eds) Farmed fish quality. Fishing News Books, London; pp 129-136.

Miyashita, S.; Sawada, Y.; Hattori, N.; Nakatsukasa, H.; Okada, T.; Murata, O. and Kumai, H. (2000). Mortality of northern bluefin tuna Thunnusthynnus due to 
trauma caused by collision during grow out culture. J World Aquacult Soc, 31:632639.

Nelson, N. (1944). A photometric adaptation of the Somogyi method for the determination of glucose, J. Biol. Chem. 153,375-380.

Noble, C.; Jones, H.A.; Damsgård, B.; Flood, M.J.; Midling, K.Ø.; Roque, A. and Cottee, S.Y. (2012). Injuries and deformities in fish: their potential impacts upon aquacultural production and welfare. Fish physiol biochem, 38(1), 61-83.

North, B.P.; Turnbull, J.F.; Ellis, T.; Porter, M.J.; Migaud, H.; Bron, J. and Bromage, N.R. (2006). The impact of stocking density on the welfare of rainbow trout (Oncorhynchus mykiss). Aquaculture, 255:466-479.

Olayemi, A.B. (1993). Survival of Eschersia coli and some pathogenic bacteria in pond water exposed to solar and UV irradiation. Biosci Res Commun, 5:11-127.

Ortuno, J.; Esteban, M. and Meseguer, J. (2001). Effects of short-term crowding stress on the gilthead seabream (Sparusaurata L.) innate immune response. Fish Shellfish Immunol, 11:187-197.

Palíková, M.; Kopp, R.; Mareš, J.; Navrátil, S.; Kubíček, Z.; Chmelař, L.; Band’ouchová, H. and Pikula, J. (2010). Selected haematological and biochemical indices of Nile tilapia (Oreochromis niloticus) reared in the environment with cyanobacterial water bloom. Acta Vet Brno, 79(9), 63-71.

Palti, Y.; Tinman, S.; Cnaani, A.; Avidar, Y.; Ron, M. and Hulata, G. (1999). Comparative study of biochemical and nonspecicc immunological parameters in two tilapia species (Oreochromis aureus and O. mossambicus). Isr. J Aquacult./Bamidgeh, 51: 48-156.

Person-Le Ruyet, J. and Le Bayon, N. (2009). Effects of temperature, stocking density and farming conditions on fin damage in European sea bass (Dicentrarchus labrax). Aquat Living Resour. 22:349-362.

Pickering, A.D. (1984). Cortisol-induced lymphocytopenia in brown trout, Salmotrutta L. Gen Comp Endocrinol, 53: 252-259.

Poli, B.M.; Parisi, G.; Scappini, F. and Zampacavallo, G. (2005). Fish welfare and quality as affected by pre-slaughter and slaughter management. Aquacult Int, 13: 29-49.

Poli, B.M. (2009). Farmed fish welfare-suffering assessment and impact on product quality. Ital J anima Sci, vol. 8 (Suppl. 1), 139- 160.

Randall, D.J. and Tsui, T.K.N. (2002). Ammonia toxicity in fish. Marine Poll Bull, 45:17-23.

Rapatsa, M.M. and Moyo, N.A.G. (2013). Performance evaluation of chicken, cow and pig manure in the production of natural fish food in aqua dams stocked with Oreochromis mossambicus. Phys Chem Earth, 66: 68-74.

Roques, J.A.C.; Abbink, W.A.; Geurds, F.B.; van de Vis, H.A. and Flik, G. (2010). Tailfin clipping, a painful procedure: Studies on Nile tilapia and common carp. Physiol Behav, 101:533-540.

Roques, J. A.; Abbink, W.; Chereau, G.; Fourneyron, A.; Spanings, T.; Burggraaf, D.; Bos, R.; Vis, H. and Flik, G. (2012). Physiological and behavioral responses to an electrical stimulus in Mozambique tilapia (Oreochromis mossambicus). Fish physiol biochem, 38(4):1019-1028.

Ross, P.S. (2000). Marine mammals as sentinels in ecological risk assessment. Hum Ecol Risk Assess, 6: 29-46.

Southgate, P. and Wall, T. (2002). Welfare of farmed fish at slaughter. In Practice 23, 277. FSBI (Fisheries Society of the British Isles). Fish Welfare. Breifing Report 2. Granta Information systems. [http://www.le.ac.uk/biology/fsbi/welfare.pdf.]

Svobodova, Z.; Pravda, D. and Palackova, J. (1991). Unified methods of haematological examination of fish. Research institute of Fish Culture and Hydrobiology, Vodnany, Methods No. 20, p. 31. 
Turnbull, J. F.; Richards, R. H. and Robertson, D. A. (1996). Gross, histological and scanning electron microscopic appearance of dorsal fin rot in farmed Atlantic salmon, Salmosalar L., parr. J. Fish Dis., 19: 415-427.

Vagsholm, I. and Djupvik, O. H. (1998). Risk factors for skin lesions in Atlantic salmon, Salmosalar L. J Fish Dis, 21:449-454.

Wall, A. J. (2001). Ethical considerations in the handling and slaughter of farmed fish. In: Kestin SC, Warriss PD (eds) Farmed fish quality. Fishing News Books, Blackwell science, Oxford; pp 108-115.

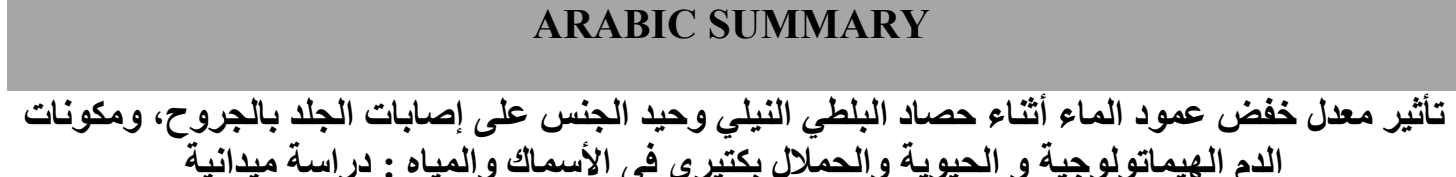

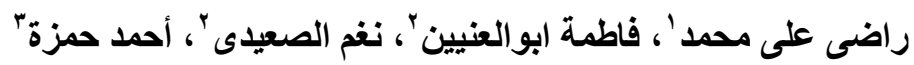

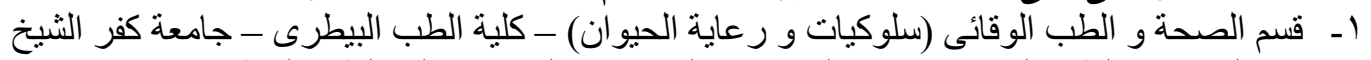

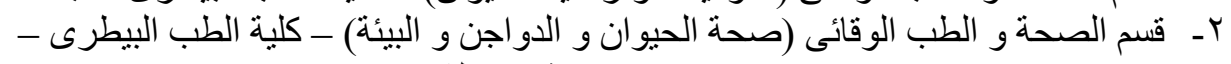

$$
\begin{aligned}
& \text { جامعة كفر الثيخ الثيخ } \\
& \text { r- استشارى جودة الأسماك و الصحة العامة_ الهيئة العامة للخدمات البيطرية ـ فرع كفر الثيخ، مصر . }
\end{aligned}
$$

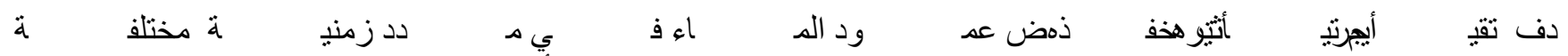

$$
\begin{aligned}
& \text { على صحة وار احة البلطي النيلي (Oreochromis niloticus) أثناء الحصاد. }
\end{aligned}
$$

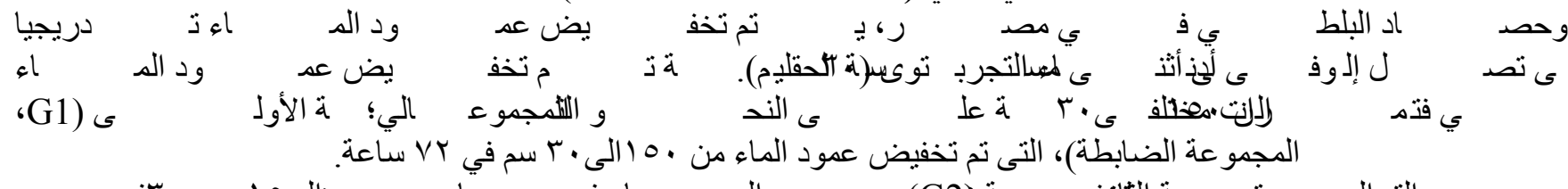

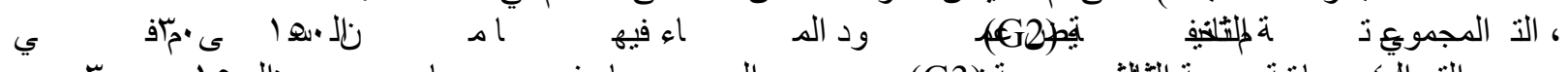

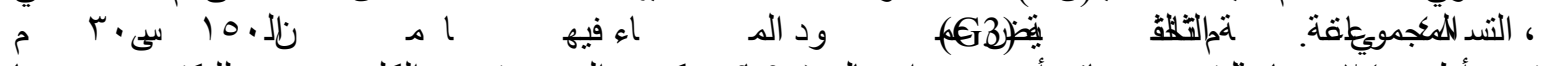

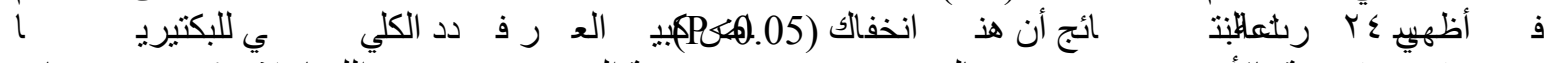

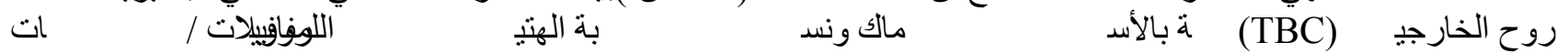

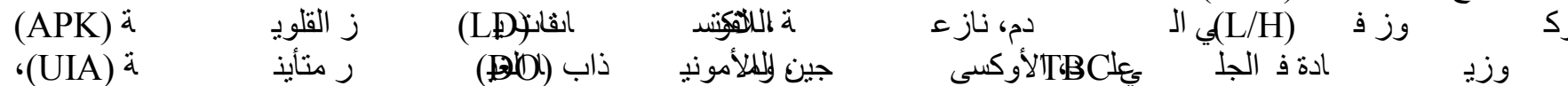

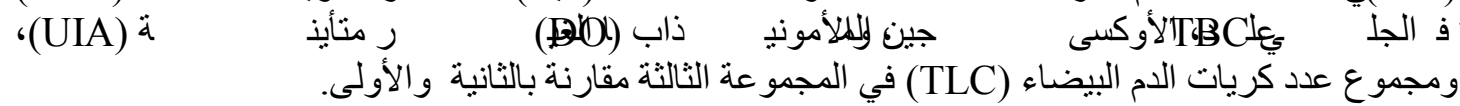

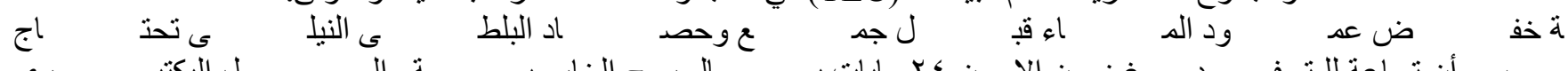

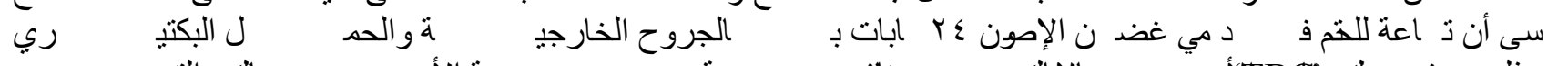

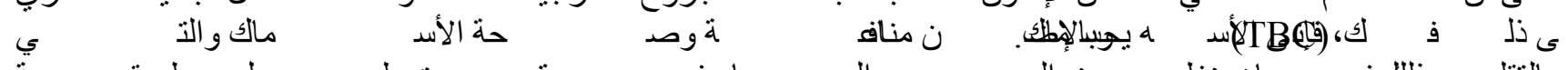

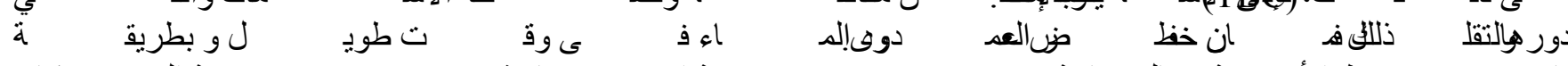

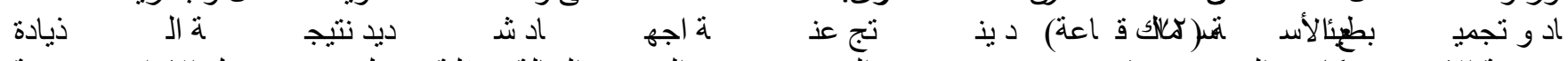

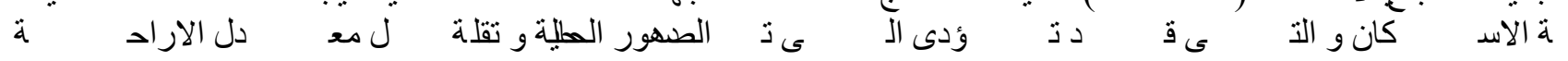

$$
\begin{aligned}
& \text { فى البلطي النيلي. }
\end{aligned}
$$

